\title{
GMR
}

\section{Genetic parameters and path analysis in cowpea genotypes grown in the Cerrado/Pantanal ecotone}

\author{
K.V. Lopes ${ }^{1}$, P.E. Teodoro ${ }^{2}$, F.A. Silva ${ }^{3}$, M.T. Silva ${ }^{1}$, R.L. Fernandes ${ }^{1}$, \\ T.C. Rodrigues ${ }^{1}$, T.C. Faria ${ }^{1}$ and A.M. Corrêa ${ }^{1}$ \\ ${ }^{1}$ Departamento de Fitotecnia, \\ Universidade Estadual de Mato Grosso do Sul, Aquidauana, MS, Brasil \\ ${ }^{2}$ Laboratório de Biometria, Departamento de Biologia Geral, \\ Universidade Federal de Viçosa, Viçosa, MG, Brasil \\ ${ }^{3}$ Laboratório de Melhoramento Vegetal, \\ Universidade Estadual do Norte Fluminense Darcy Ribeiro, \\ Campos dos Goytacazes, RJ, Brasil \\ Corresponding author: P.E. Teodoro \\ E-mail: eduteodoro@hotmail.com
}

Genet. Mol. Res. 16 (2): gmr16029559

Received November 30, 2016

Accepted April 6, 2017

Published May 18, 2017

DOI http://dx.doi.org/10.4238/gmr16029559

Copyright $(2017$ The Authors. This is an open-access article distributed under the terms of the Creative Commons Attribution ShareAlike (CC BY-SA) 4.0 License.

\begin{abstract}
Estimating genetic parameters in plant breeding allows us to know the population potential for selecting and designing strategies that can maximize the achievement of superior genotypes. The objective of this study was to evaluate the genetic potential of a population of 20 cowpea genotypes by estimating genetic parameters and path analysis among the traits to guide the selection strategies. The trial was conducted in randomized block design with four replications. Its morphophysiological components, components of green grain production and dry grain yield were estimated from genetic use and correlations between the traits. Phenotypic correlations were deployed through path analysis into direct and indirect effects of morphophysiological traits and yield components on dry grain yield. There were significant differences $(\mathrm{P}<0.01)$ between the genotypes
\end{abstract}

Genetics and Molecular Research 16 (2): gmr16029559 
for most the traits, indicating the presence of genetic variability in the population and the possibility of practicing selection. The population presents the potential for future genetic breeding studies and is highly promising for the selection of traits dry grain yield, the number of grains per pod, and hundred grains mass. A number of grains per green pod is the main determinant trait of dry grain yield that is also influenced by the cultivar cycle and that the selection for the dry grain yield can be made indirectly by selecting the green pod mass and green pod length.

Key words: Vigna unguiculata (L.) Walp.; Genetic variability; Selection; Genotypic correlation

\section{INTRODUCTION}

Cowpea (Vigna unguiculata (L.) Walp.) is an extremely rustic species, short cycle, undemanding in soil fertility and tolerant to high temperatures (Santos et al., 2015). Its low yield grain $(503.2 \mathrm{~kg} / \mathrm{ha})$ can be attributed to the low technology level employed in its cultivation and, among the main limiting causes, it is worth mentioning the use of traditional cultivars with low productive potential (Santos et al., 2014b). However, under experimental conditions, dry grain yield above $3000 \mathrm{~kg} / \mathrm{ha}$ with the expectation that the species genetic potential exceeds $6000 \mathrm{~kg} /$ ha (Freire Filho et al., 2005). Therefore, it is necessary to intensify research to generate sufficient information about the genetic components and to contribute to developing superior genotypes.

Estimating genetic parameters in a population such as coefficient of genetic variation, heritability and correlation coefficients among traits allow knowing the genetic variability, the expression degree of the trait from one generation to another and the possibility of gains through direct or indirect selection. Several studies have already demonstrated the productive potential of cowpea in the Cerrado-Pantanal ecotone region (Santos et al., 2014b,c, 2015; Teodoro et al., 2015a,b; Torres et al., 2015a,b, 2016; Barroso et al., 2016).

Cowpea-breeding programs aim to select genotypes with high grain yield, low size and reduced cycle, and which have good commercial aspect. In this sense, knowing the association between these traits enables the breeder to explore the possibility of indirect selection in cases of traits with complex inheritance and low heritability, such as grain yield. Estimates of correlation coefficient make it possible to evaluate the magnitude and direction of the relationship between two traits, and consequently the possibility of obtaining gains for one of them using indirect selection via the other trait. In some cases, indirect selection based on the correlated response can be more effective and faster than the direct selection of the desired trait. However, the quantification and interpretation of the magnitude of a correlation coefficient may result in misunderstandings in the selection strategies in a breeding program, since high correlation between two traits may be the result of the effect of a third or more traits on the first ones (Cruz et al., 2012).

To better understand the causes involved in the associations among traits, Wright (1923) proposed a method called path analysis, which consists in splitting the correlations into direct and indirect effects from several traits on the main variable called the basic variable. Estimates of effects are obtained by regression equations in which the original variables are previously standardized, making it possible through the path coefficients, for measuring the direct influence of one variable on the other, independent of the others, in the context of cause and effect relationships. The use of this analysis considering grain yield as the main dependent

Genetics and Molecular Research 16 (2): gmr16029559 
variable is important for cowpea breeding programs, as it will aid in the selection strategies of more productive genotypes. Thus, this study aimed to estimate genetic parameters in a population of 20 cowpea genotypes grown in the Cerrado/Pantanal ecotone to assess their potential and to investigate the associations between traits to target selection strategies in breeding programs with this crop.

\section{MATERIAL AND METHODS}

\section{Trial conduction}

The trial was conducted between April and July of the agricultural year 2014/2015, in the experimental area of the State University of Mato Grosso do Sul, University Unit of Aquidauana, located at $20^{\circ} 27^{\prime} 00^{\prime \prime} \mathrm{S}$ and $55^{\circ} 48^{\prime} 00^{\prime \prime} \mathrm{W}$, the average altitude of $170 \mathrm{~m}$. Region climate, according to the classification described by Köppen-Geiger is Savanna Tropical (Aw) with average annual rainfall of $1200 \mathrm{~mm}$ and average annual temperature of $26^{\circ} \mathrm{C}$. Area soil was identified as Ultisol dystrophic and texture, moderately deep, well drained and of good fertility, according to soil chemical analysis data (Table 1).

Table 1. Soil chemical analysis of the experimental area.

\begin{tabular}{|c|c|c|c|c|c|c|c|c|c|}
\hline \multirow{2}{*}{ Depth $(\mathrm{cm})$} & \multirow{2}{*}{$\mathrm{H}_{2} \mathrm{O}(\mathrm{pH})$} & $\mathrm{Al}$ & $\mathrm{Ca}+\mathrm{Mg}$ & $\mathrm{K}$ & \multirow{2}{*}{$\frac{\mathrm{P}}{\mathrm{mg} / \mathrm{dm}^{-3}}$} & \multirow{2}{*}{$\frac{\mathrm{O} . \mathrm{M}}{\mathrm{g} / \mathrm{dm}^{-3}}$} & V & $\mathrm{m}$ & \multirow{2}{*}{$\begin{array}{c}\text { CEC } \\
\mathrm{cmol}^{2} / \mathrm{dm}^{-3}\end{array}$} \\
\hline & & & $\mathrm{nol}_{\mathrm{c}} / \mathrm{dm}^{-3}$ & & & & & & \\
\hline $0-20$ & 6.2 & 0.0 & 4.31 & 0.2 & 41.3 & 19.74 & 45 & 0 & 5.1 \\
\hline
\end{tabular}

The experimental design was randomized blocks, with 20 treatments and four replications. The experimental unit consisted of four plant lines with $5 \mathrm{~m}$ of length each, spaced $0.50 \mathrm{~m}$, considering as a useful area only the two central plot lines. The genotypes used were from the germplasm bank of the Embrapa Meio-Norte, PI (EMBRAPA - CNPAF), located at Teresina, PI, and consisted of cultivars and advanced lineages (Table 2).

Table 2. Parental, origin and commercial subclass of 20 cowpea genotypes evaluated in Aquidauana, MS, Brazil, (2015).

\begin{tabular}{|c|c|c|}
\hline Genotype & Parental/Provenance & Commercial sub-class \\
\hline MNC04-762F-3 & TE96-282-22G x (Te96-282-22G x Vita 7) & $\mathrm{BL}$ \\
\hline MNC04-762F-9 & TE96-282-22G x (Te96-282-22G x Vita 7) & $\mathrm{BL}$ \\
\hline MNC04-769F-30 & CE-315 x TE97-304G-12 & ML \\
\hline MNC04-769F-48 & CE-315 x TE97-304G-12 & ML \\
\hline MNC04-792F-146 & MNC00-553D-8-1-2-3 x TV x 5058-09C & ML \\
\hline MNC04-769F-62 & CE-315 $\times$ TE97-304G-12 & ML \\
\hline MNC04-782F-104 & (TE97-309G-24 x TE96-406-2E-28-2) x TE97-309G-24 & SV \\
\hline MNC04-792F-143 & MNC00-553D-8-1-2-3 x TV x 5058-09C & ML \\
\hline MNC04-792F-144 & MNC00-553D-8-1-2-3 x TV x 5058-09C & SV \\
\hline MNC04-792F-148 & MNC00-553D-8-1-2-3 x TV x 5058-09C & ML \\
\hline MNC04-795F-153 & MNC99-518G-2 x IT92KD-279-3 & ML \\
\hline MNC04-795F-154 & MNC99-518G-2 x IT92KD-279-3 & SV \\
\hline MNC04-795F-155 & MNC99-518G-2 x IT92KD-279-3 & ML \\
\hline MNC04-795F-159 & MNC99-518G-2 x IT92KD-279-3 & ML \\
\hline MNC04-795F-168 & MNC99-518G-2 x IT92KD-279-3 & BR \\
\hline BRS Guariba & IT85F-2687 x TE87-98-8G & BL \\
\hline BRS Tumucumaque & TE96-282-22G x IT87D-611-3 & $\mathrm{BL}$ \\
\hline BRS Novaera & TE97-404-IF x TE97-404-3F & $\mathrm{BR}$ \\
\hline BRS Itaim & MNC01-625-10-1-2-5 x MNC99-544D-101-2-2 & FR \\
\hline BRS Cauamé & TE93-210-13F x TE96-282-22G & $\mathrm{BL}$ \\
\hline
\end{tabular}

Commercial types: $\mathrm{BL}=$ plain white $\mathrm{BR}=$ rough white $\mathrm{FR}=$ fradinho $\mathrm{ML}=$ mulato; $\mathrm{SV}=$ evergreen.

Genetics and Molecular Research 16 (2): gmr16029559 
The soil was prepared in tillage system (one harrow and two gradients). The grooves were mechanically opened with a depth from 5 to $7 \mathrm{~cm}$. Seeds were treated with fungicide based on Carboxin and Thiran, using $250 \mathrm{~mL}$ of the commercial product per $100 \mathrm{~kg}$ seeds. Seeding was performed on April 25, 2015, manually, using the density of 16 seeds per meter. Two weeks after the emergency, the manual thinning was done leaving eight seedlings per meter. Fertilization was not carried out at sowing and cover due to the natural crop rusticity and the soil fertility level (Table 1). Plots were kept in the clean until the full crop establishment and closing between the lines by manual weeding, carried out weekly.

Harvest was performed in the period from August 8 to 15, 2015, performed manually. In each plot, the pods were harvested when completely dried and later trodden by "batting" with flexible rods, after proceeding to clean with the aid of appropriate mesh sieves. For evaluating production components, pods were harvested at physiological maturation (change in color of the pod).

\section{Evaluated traits}

The following traits were evaluated:

- Days to flowering (DF): period considered in days between the early emergence of seedlings to the appearance of the first open flower on the plot;

- Days to physiological maturity (DM): period considered in days between the early emergency to appearance of the first pod with modified color on the plot;

- Number of branches per plant (NBP): it was determined randomly considering ten plants in the useful area of each plot and proceeding to the counting of secondary branches originating from the main stem;

- Main stem length (MSL): it was determined to employ a measuring tape, considering randomly ten plants in the useful area of each plot, measuring the distance between the ground and the apex of the main stem of the plant;

- Green pod length (GPL): ten pods were collected at the physiological maturation, randomly, in the useful area of each plot, whose length was measured with the aid of a ruler;

- Green pod mass (GPM): the same ten pods harvested and used for measuring the length were threshed and had their masses weighed in semi-analytic electronic scale;

- Number of grains per green pod (NGP): it was made the counting of whole grains of the ten pods harvested at physiological maturity;

- Hundred green grains mass (HGM): a hundred grains, harvested from the pods at physiological maturation, it had its mass determined in semi-analytic electronic balance;

- Dry grain yield (YIE): dry grain yield at $\mathrm{kg} / \mathrm{ha}$ was estimated based on the production obtained in central rows of the plot area, extrapolating the value obtained for $\mathrm{kg} / \mathrm{ha}$.

\section{Statistical analysis}

Data obtained were initially submitted to the Shapiro-Wilk test $(\mathrm{P}<0.05)$ to verify the data normality. The scheme used in analysis of variance was the randomized blocks, considering the effect of genotype and blocks as fixed and the error as random, adopting the statistical model described in Equation 1.

$$
Y_{i j}=\mu+g_{i}+b_{j}+\varepsilon_{i j}
$$

Genetics and Molecular Research 16 (2): gmr16029559 
where $Y_{i j}$ : observed value of the $i$-th genotype in the $j$-th block; $\mu$ : overall mean of the trial; $g_{i}$ : effect of the $i$-th genotype $(i=1,2, \ldots, \mathrm{g}) ; b_{j}$ : effect of the $j$-th block $(j=1,2 \ldots, \mathrm{r}) ; \varepsilon_{i j}$ : random error associated with observation $Y_{i j}$.

After analysis of variance by the F-test, the means were grouped by the Scott and Knott test at $5 \%$ probability of occurrence of type I error. The following genetic parameters were estimated: mean environmental variance (2), phenotypic (3) and mean genotypic variance (4); experimental coefficient of variation (5); genotypic coefficient of variation (6); genotypic coefficient of determination (7); b quotient (8); environmental correlation (9); phenotypic correlation (10); and genotypic correlation (11) represented, respectively, by the following estimators (Johnson et al., 1955):

$$
\begin{gathered}
\mathrm{V}_{\mathrm{p}}=\frac{\mathrm{MS}_{\mathrm{r}}}{\mathrm{k}} \\
\mathrm{V}_{\mathrm{g}}=\frac{\mathrm{MS}_{\mathrm{g}}}{\mathrm{k}} \\
\mathrm{V}_{\mathrm{e}}=\frac{\mathrm{MS}_{\mathrm{g}}-\mathrm{MS}_{\mathrm{r}}}{\mathrm{k}} \\
\mathrm{CV}_{\mathrm{g}}=\left(\frac{\sqrt{\hat{\sigma}_{\mathrm{G}}^{2}}}{\mathrm{~m}}\right) \times 100 \\
\mathrm{CV}_{\mathrm{e}}=\left(\frac{\sqrt{\mathrm{MS}}}{\mathrm{m}}\right) \times 100 \\
\hat{\mathrm{r}}_{\mathrm{F}}=\frac{\mathrm{COV_{ \textrm {F } ( \mathrm { xy } ) }}}{\sqrt{\hat{\sigma}_{\mathrm{Fx}}^{2} \times \hat{\sigma}_{\mathrm{Fy}}^{2}}} \\
\hat{\mathrm{R}}^{2}=\frac{\hat{\sigma}_{\mathrm{G}}^{2}}{\hat{\sigma}_{\mathrm{F}}^{2}} \\
\hat{\sqrt{\hat{\sigma}_{\mathrm{Ex}}^{2} \times \hat{\sigma}_{\mathrm{Ey}}^{2}}} \\
\hat{C V}_{\mathrm{g}} \\
\mathrm{CV}_{\mathrm{e}}
\end{gathered}
$$

Genetics and Molecular Research 16 (2): gmr16029559 


$$
\hat{\mathrm{r}}_{\mathrm{G}}=\frac{\operatorname{COV}_{\mathrm{G}(\mathrm{xy})}}{\sqrt{\hat{\sigma}_{\mathrm{Gx}}^{2} \times \hat{\sigma}_{\mathrm{Gy}}^{2}}}
$$

(Equation 11)

where $\hat{\mathrm{r}}_{\mathrm{xy}}=$ correlation among the traits $\mathrm{X}$ and $\mathrm{Y} ; \mathrm{COV}_{\mathrm{xy}}=$ covariance among the traits $\mathrm{X}$ and $\mathrm{Y} ; \hat{\sigma}_{\mathrm{x}}^{2}$ and $\hat{\sigma}_{\mathrm{y}}^{2}=$ variance of the traits $\mathrm{X}$ and $\mathrm{Y}$, respectively. In order to graphically express the functional relationship between the estimates of the phenotypic correlation coefficients between the traits, correlation network was used, in which the proximity between the nodes (traces) is proportional to the absolute value of the correlation between these nodes. The thickness of the edges was controlled by applying a cut-off value of 0.60 , which means that only $\left|\mathrm{r}_{\mathrm{ij}}\right| \geq 0.60$ has their edges highlighted. Finally, positive correlations were highlighted in green, while negative correlations were represented in red.

After checking weak multicollinearity in the matrix $\hat{\mathbf{r}}_{\mathrm{F}}$, these were deployed in direct and indirect effects, considering the following Equation 12:

$$
Y=p_{1} X_{1}+p_{2} X_{2}+\ldots+p_{n} X_{n}+p_{\varepsilon} u
$$

(Equation 12)

where $\mathrm{Y}$ is the principal dependent variable grain yield; $\mathrm{X}_{1}, \mathrm{X}_{2}, \ldots, \mathrm{x}_{\mathrm{n}}$ : are the explanatory independent variables; $\mathrm{p}_{1}, \mathrm{p}_{2}, \ldots, \mathrm{p}_{\mathrm{n}}$ : are the coefficients of path analysis. The coefficient of determination was calculated by the expression $\mathrm{R}^{2}=\mathrm{p}_{1 \mathrm{y}}{ }^{2}+\mathrm{p}_{2 \mathrm{y}}{ }^{2}+\ldots 2 \mathrm{p}_{2 \mathrm{y}} \mathrm{p}_{2 \mathrm{n}} \mathrm{r}_{2 \mathrm{n}}$. All statistical analyzes were performed with the GENES software (Cruz, 2013) and followed the procedures recommended by Cruz et al. (2012).

\section{RESULTS AND DISCUSSION}

There were significant differences $(\mathrm{P}<0.01)$ between the genotypes for the traits DM, MSL, HGM, GPL, NGP, and YIE, indicating the presence of genetic variability in the population and the possibility of practicing selection for these traits (Table 3). However, for the traits DF, NBP, and GPM the genotype effect was not significant, which limits the gains with the selection in the same ones.

Table 3. Summary of analysis of variances for agronomic traits evaluated in 20 cowpea genotypes cultivated in the Cerrado/Pantanal ecotone.

\begin{tabular}{l|c|c|c|c|c|c}
\hline SV & d.f. & DF & DM & MSL & NBP & HGM \\
\hline Blocks & 3 & 171.03 & 73.81 & 308.52 & 6.05 & 1.19 \\
\hline Genotypes & 19 & $43.36^{\text {ns }}$ & $39.85^{* *}$ & $402.11^{*}$ & $1.23^{\text {ns }}$ & $13.19^{* *}$ \\
\hline Residue & 57 & 35.82 & 14.36 & 199.29 & 0.91 & 1.31 \\
\hline Mean & - & 51.30 & 75.84 & 49.52 & 8.45 & 18.30 \\
\hline F-test & - & 1.21 & 2.78 & 2.02 & 1.36 & 10.05 \\
\hline CV $_{\text {e }}$ ) & - & 11.67 & 4.99 & 28.51 & 11.28 & YIE \\
\hline SV & d.f. & GPL & GPM & NGP & 96015.53 \\
\hline Blocks & 3 & 4.59 & 985.15 & 9.01 & $168503.95^{* *}$ \\
\hline Genotypes & 19 & $7.42^{* *}$ & $194.37^{\text {ns }}$ & $6.72^{* *}$ & 11452.46 \\
\hline Residue & 57 & 1.52 & 132.80 & 1.34 & 742.75 \\
\hline Mean & - & 18.05 & 83.52 & 10.71 & 14.71 \\
\hline F-test & - & 4.87 & 1.46 & 5.00 & 10.82 & 14.41 \\
\hline CV $(\%)$ & - & 6.84 & 13.79 & & 10.82 \\
\hline
\end{tabular}

d.f.: degrees of freedom; DF: days to flowering; DM: days to physiological maturity; NBP: number of branches per plant; MSL: main stem length; GPL: green pod length; GPM: green pod mass; NGP: number of grains per green pod; HGM: hundred green grains mass; YIE: dry grain yield; $\mathrm{CV}_{\mathrm{e}}$ : environmental coefficient of variation; $\mathrm{CV}$ : coefficient of variation. ${ }^{*}$ Significant at $1 \%$. $*$ Significant at $5 \%$. ${ }^{\text {ns }}$ Not significant at $5 \%$ probability.

Genetics and Molecular Research 16 (2): gmr16029559 
Environmental coefficient of variation $\left(\mathrm{CV}_{\mathrm{e}} \%\right)$, in general, indicated good experimental precision for all evaluated traits, since the magnitude of this parameter was less than $15 \%$, except for the MSL, which obtained an estimate more than 20\%. According to Cruz et al. (2012), values of CV lower than $20 \%$ denote excellent environmental control in phenotypic traits with continuous distribution. In this way, it can be affirmed that the experimental design used contributed to minimize the non-controllable effects. Teófilo et al. (2008), evaluating several traits in cowpea genotypes, observed estimates of CV varying from $4.34 \%$ (HGM) to $30.77 \%$ (YIE), while Silva and Neves (2011) found for YIE CV estimates of $45.98 \%$, and in both cases the estimates for this trait were superior to those obtained in this study.

We can verify in Table 4 that residual variance $\left(\mathrm{V}_{\mathrm{e}}\right)$ was superior to genotypic variance $\left(\mathrm{V}_{\mathrm{g}}\right)$ for the traits in which genotype effects were not significant (DF, NBP, and GPM). For the other traits, $\mathrm{V}_{\mathrm{g}}$ was the main fraction of the phenotypic variance $\left(\mathrm{V}_{\mathrm{p}}\right)$, indicating that the observed differences are from genetic nature. In plant breeding, it is fundamental to obtain estimates of genetic parameters, allowing to identify the gene action nature involved in the control of the quantitative traits and to evaluate the efficiency of different breeding strategies to obtain genetic gains and to maintain adequate genetic basis in populations (Câmara et al., 2007).

Table 4. Summary of analysis of variances for agronomic traits evaluated in 20 cowpea genotypes cultivated in the Cerrado/Pantanal ecotone (2015).

\begin{tabular}{|c|c|c|c|c|c|}
\hline Parameter & DF & DM & MSL & NBP & HGM \\
\hline $\mathrm{V}_{\mathrm{p}}$ & 10.84 & 9.97 & 100.53 & 0.31 & 3.29 \\
\hline $\mathrm{V}_{\mathrm{e}}$ & 8.96 & 3.59 & 49.82 & 0.23 & 0.33 \\
\hline $\mathrm{V}_{\mathrm{g}}$ & 1.88 & 6.37 & 50.70 & 0.08 & 2.97 \\
\hline $\mathrm{R}^{2}(\%)$ & 17.38 & 63.97 & 50.44 & 26.49 & 90.05 \\
\hline $\mathrm{CV}_{\mathrm{g}}(\%)$ & 2.68 & 3.33 & 14.38 & 3.39 & 9.41 \\
\hline $\mathrm{b}\left(\mathrm{CV}_{\mathrm{g}} / \mathrm{CV}_{\mathrm{e}}\right)$ & 0.23 & 0.67 & 0.50 & 0.30 & 1.50 \\
\hline Parameter & GPL & GPM & NGP & \multicolumn{2}{|c|}{ YIE } \\
\hline $\mathrm{V}_{\mathrm{p}}$ & 1.85 & 48.59 & 1.68 & \multicolumn{2}{|c|}{42125.98} \\
\hline $\mathrm{V}_{\mathrm{e}}$ & 0.38 & 33.20 & 0.34 & \multicolumn{2}{|c|}{2863.11} \\
\hline $\mathrm{V}_{\mathrm{g}}$ & 1.47 & 15.39 & 1.34 & \multicolumn{2}{|c|}{39262.88} \\
\hline $\mathrm{R}^{2}(\%)$ & 79.46 & 31.67 & 80.00 & \multicolumn{2}{|c|}{93.20} \\
\hline $\mathrm{CV}_{\mathrm{g}}(\%)$ & 6.72 & 4.69 & 10.82 & \multicolumn{2}{|c|}{26.68} \\
\hline $\mathrm{b}\left(\mathrm{CV}_{\mathrm{g}} / \mathrm{CV}_{\mathrm{e}}\right)$ & 0.98 & 0.34 & 1.00 & \multicolumn{2}{|c|}{1.85} \\
\hline
\end{tabular}

$\mathrm{Vp}$ : phenotypic variance; $\mathrm{V}_{\mathrm{g}}$ : genotypic variance; $\mathrm{V}_{\mathrm{e}}$ : environmental variance; $\mathrm{R}^{2}$ : genotypic coefficient of determination; $\mathrm{CV}_{\mathrm{g}}$ : genotypic coefficient of variation; b quotient: $\left(\mathrm{CV}_{\mathrm{g}} / \mathrm{CV}_{\mathrm{e}}\right)$. For agronomic trait abbreviations, see Table 3 .

Cruz et al. (2012) mention that when the adopted statistical model considers the genotypes as fixed effect, such as in the present study, the heritability passes to be denominated genotypic coefficient of determination $\left(\mathrm{R}^{2}\right)$. Genotypic coefficient of determination ranged from $50.44 \%$ for MSL to $93.20 \%$ for YIE. Similar results were found by Bertini et al. (2009), where $\mathrm{R}^{2}$ ranged from 74.19 (GPL) to $93.33 \%$ for YIE. However, Silva and Neves (2011) found different estimates for the most quantitative cowpea traits, except for YIE.

The traits GPL, NGP, HGM, and YIE showed the highest estimates of $\mathrm{R}^{2}(>75 \%)$, allowing to infer that the studied population is highly promising for the selection. However, it should be emphasized that YIE is a complex trait, resulting from the expression and association of different traits, highly influenced by the environment. Thus, the high values of $\mathrm{R}^{2}$ obtained in this study may be overestimated by the interaction genotype $\mathrm{x}$ environments, since the trial was carried out only 1 year and in a single place.

Genetics and Molecular Research 16 (2): gmr16029559 
Regis et al. (2014) evaluating twenty cowpea genotypes in the region of Aquidauana, MS, found estimates of $\mathrm{R}^{2}$ in magnitude similar to those obtained in this study. Estimates of $\mathrm{R}^{2}$ for DM and MSL were 63.97 and $50.44 \%$, respectively, values considered as median according to Correa et al. (2012). These results allow inferring about possible difficulties in successive selection cycles for these traits as a result of lower expected genetic gain per cycle.

From the traits evaluated, the one that presented the lowest estimate of $\mathrm{R}^{2}$ was $\mathrm{DF}$ $(17.38 \%)$, disagreeing with the results observed by Bertini et al. (2009). Estimates of $\mathrm{R}^{2}$ of $17.38 \%$ is indicative of the expressive participation of the environmental variance in the phenotypic expression of this trait, causing the reduction of the genetic gain expected by selection, thus making the population not promising for its selection. A similar result was obtained by Correa et al. (2015), who also found low estimate of $\mathrm{R}^{2}$ for this trait.

Genotypic coefficient of variation $\left(\mathrm{CV}_{\mathrm{g}}\right)$ showed estimates that varied from $3.33 \%$ for DM to $26.68 \%$ for YIE. This parameter allows to make inference about the genetic variability in the different traits, as well as the genotypic coefficient of determination $\left(\mathrm{R}^{2}\right)$. Higher estimates of $\mathrm{CVg}$ above $20 \%$ (Correa et al, 2003) are indicative that the population is promising for the selection of the trait under study, and significant selection gains should be expected. For the traits studied, only YIE presented an estimate above $20 \%$. Mean values,between 10 and $20 \%$, were observed for the traits NGP and MSL, allowing to infer possible difficulties in the selection of these traits, while for the others the estimates were below $10 \%$.

The ratio $\mathrm{CV}_{\mathrm{g}} / \mathrm{CV}_{\mathrm{e}}$ (b quotient) allows inferences about the possibilities of success in improving a population. According to Vencovsky (1978), estimates of $b \geq 1$ indicate the possibility of success in selecting a given trait, contributing to the selection of genotypes with superior performance. Estimates of $b$ ranged from 0.67 for DM to 1.85 for YIE. The traits HGM, NGP, and YIE obtained estimates of $\mathrm{b}$ higher than 1.0 and, thus, show promising for selection of superior genotypes. For DM, MSL, GPL, and GPM, estimates of $b$ were less than 1.0, which indicates greater difficulties for the selection of the same ones whose phenotypic expressions are more influenced by the environment.

Joint variation of two traits that are being evaluated is explained by the genotypic correlation through genetic mechanisms. Thus, it is important for the breeder to know the degree of association between traits of agronomic importance, mainly because the selection on one trait changes the behavior of others (Correa et al., 2003). Genotypic, phenotypic, and environmental correlations were shown in Table 5. The highest positive correlations were observed between the pairs of traits: GPM x NGP (0.98); NGP x HGM (0.94); GPL x GPM (0.91); GPM x YIE (0.83); NGP x YIE (0.75); DF x NBP (0.72), and GPL x NGP (0.71). We observed that from the cowpea grain production components, the traits GPM and NGP are those that correlate more directly with the grain yield, allowing infer about the possibility of indirect selection for increasing the yield through these traits.

The higher positive correlation between the production components was observed between the GPM x NGP (0.98). This was expected because in the determination of the green pod mass, green grains were also considered. Correa et al. (2015) also found estimates of high and significant genotypic correlations for the GPM x NGP. Negative and significant genotypic correlations were observed between pairs of traits: MSL x GPM (-0.93); NBP x GPL (-0.88); NBP x GPM (-0.96); GPL x HGM (-0.90), and GPM x HGM (-0.93). Negative and significant correlations between the production components GPL x HGM and GPM x HGM can be explained by the compensation between the production components (Castoldi, 1991), so that the increase in green pod length may lead to a reduction in the grain mass and/or in the green pod mass, and vice versa.

Genetics and Molecular Research 16 (2): gmr16029559 
Table 5. Genotypic $\left(r_{g}\right)$, phenotypic $\left(r_{p}\right)$, and environmental $\left(r_{e}\right)$ correlations between traits of 20 cowpea genotypes (Aquidauana, MS, Brazil, 2015).

\begin{tabular}{|c|c|c|c|c|c|c|c|c|c|}
\hline Characters & & DM & MSL & NBP & GPL & GPM & NGP & HGM & YIE \\
\hline \multirow[t]{3}{*}{ DF } & $\mathrm{r}_{\mathrm{p}}$ & 0.15 & -0.11 & 0.08 & 0.07 & 0.14 & 0.20 & -0.12 & 0.41 \\
\hline & $\mathrm{rg}$ & -0.32 & -0.32 & 0.72 & 0.37 & 0.66 & 0.52 & -0.18 & 0.53 \\
\hline & $r_{e}$ & 0.12 & -0.02 & -0.10 & -0.16 & -0.02 & 0.02 & -0.16 & -0.02 \\
\hline \multirow[t]{3}{*}{ DM } & $r_{p}$ & 1.00 & -0.21 & -0.16 & 0.06 & 0.36 & 0.13 & -0.24 & 0.28 \\
\hline & $\mathrm{rg}_{\mathrm{g}}$ & & -0.38 & -0.39 & 0.03 & 0.56 & 0.21 & -0.31 & 0.39 \\
\hline & $\mathrm{r}_{\mathrm{e}}$ & & 0.03 & 0.02 & 0.14 & 0.21 & -0.05 & 0.46 & -0.13 \\
\hline \multirow[t]{3}{*}{ MSL } & $\mathrm{r}_{\mathrm{p}}$ & & 1.00 & 0.30 & 0.02 & -0.26 & -0.31 & 0.17 & -0.08 \\
\hline & $\mathrm{rg}$ & & & -0.22 & -0.17 & -0.93 & -0.59 & 0.22 & -0.12 \\
\hline & $\mathrm{r}_{\mathrm{e}}$ & & & 0.64 & 0.40 & 0.30 & 0.19 & 0.07 & 0.01 \\
\hline \multirow[t]{3}{*}{ NBP } & $\mathrm{r}_{\mathrm{p}}$ & & & 1.00 & -0.35 & 0.42 & 0.04 & 0.07 & -0.08 \\
\hline & $\mathrm{rg}_{\mathrm{g}}$ & & & & -0.88 & -0.96 & -0.08 & 0.15 & -0.15 \\
\hline & $\mathrm{r}_{\mathrm{e}}$ & & & & 0.14 & 0.21 & 0.11 & 0.01 & -0.05 \\
\hline \multirow[t]{3}{*}{ GPL } & $\mathrm{r}_{\mathrm{p}}$ & & & & 1.00 & 0.71 & 0.66 & -0.74 & 0.47 \\
\hline & $\mathrm{rg}$ & & & & & 0.91 & 0.71 & -0.90 & 0.55 \\
\hline & $\mathrm{r}_{\mathrm{e}}$ & & & & & 0.67 & 0.47 & 0.13 & -0.05 \\
\hline \multirow[t]{3}{*}{ GPM } & $\mathrm{r}_{\mathrm{p}}$ & & & & & 1.00 & 0.68 & -0.56 & 0.45 \\
\hline & $\mathrm{rg}_{\mathrm{g}}$ & & & & & & 0.98 & -0.93 & 0.83 \\
\hline & $\mathrm{r}_{\mathrm{e}}$ & & & & & & 0.51 & 0.08 & -0.03 \\
\hline \multirow[t]{3}{*}{ NGP } & $r_{p}$ & & & & & & 1.00 & -0.81 & 0.66 \\
\hline & $\mathrm{rg}_{\mathrm{g}}$ & & & & & & & 0.94 & 0.75 \\
\hline & $\mathrm{r}_{\mathrm{e}}$ & & & & & & & -0.08 & 0.07 \\
\hline \multirow[t]{3}{*}{ HGM } & $\mathrm{r}_{\mathrm{p}}$ & & & & & & & 1.00 & -0.59 \\
\hline & $\mathrm{rg}$ & & & & & & & & -0.64 \\
\hline & $r_{e}$ & & & & & & & & -0.13 \\
\hline
\end{tabular}

DF: days to flowering; DM: days to physiological maturity; NBP: number of branches per plant; MSL: main stem length; GPL: green pod length; GPM: green pod mass; NGP: number of grains per green pod; HGM: hundred green grains mass; YIE: dry grain yield.

Negative and significant correlations between the morphological traits related to the plant architecture (MSL and NBP) and some production components (GPM and GPL) allow to infer that plants with higher vegetative growth (greater height and number of branches) are not necessarily those with highest grain yield, as can be verified by non-significant correlations between these traits and YIE, which may be related to greater translocation of photoassimilates for attending to these drains (stems and branches), to the detriment of the pods and grains.

According to Falconer (1987), phenotypic correlation measures the degree of association among two traits from the genetic and environmental effects, being it the main responsible for the correlation of low heritability traits, such as grain yield. The highest positive and significant phenotypic correlations were observed between the production components GPL x HGM ( 0.71$)$; GPL x NGP (0.66); NGP x YIE (0.66), and GPM x NGP (0.68) (Table 5). We observed that of the production components, the NGP was the one that obtained the highest phenotypic correlation with grain yield (YIE), fact also observed by Andrade et al. (2010).

Environmental correlations (Table 5) between the traits with differences in magnitude and sign in relation to the respective genotypic correlations ( $\mathrm{r}_{\mathrm{g}}$ ), according to Cruz et al. (2012) had the causes of inheritable and environment variations affecting the traits by means of different physiological mechanisms; such fact can be observed between the pairs of traits DM $x$ HGM, MSL x GPM and NBP x GPM. The existence of significant environmental correlation indicates that the two traits are influenced by the environmental conditions, when positive indicates that the variation effect is favorable to both variables and when negative favors one and disfavors another, simultaneously (Cruz et al., 2012).

Genotypic and phenotypic coefficients of correlation quantify the associations in magnitude and direction; however, they are not enough to express the direct and indirect

Genetics and Molecular Research 16 (2): gmr16029559 
effects. Path analysis allows a clearer interpretation about the direct influence of one trait on another and the interference that other traits exert on this association. Thus, it is possible to know in detail the influences of the traits involved in a previously established diagram, and to justify the existence of positive and negative correlations of high and low magnitudes among the studied traits (Santos et al., 2014a).

After unfolding the genotypic correlation, we considered the study of the influence of the morphophysiological traits(DF, DM, MSL, and NBP) and the primary production components(GPL, GPM, NGP, and HGM) on the YIE as basic variables (Table 6). Among the morphophysiological traits, DF had a greater direct effect on the YIE, which can be translated in relation of cause and effect due to the phenotypic correlation of narrow sense heritabilities observed between these traits. This demonstrates that cowpea genotypes with longer cycles are more productive. However, precocity is a desired characteristic in breeding programs of this crop, which indicates that it is necessary to recombine the best genotypes to try to break this unfavorable association.

Table 6. Estimates of direct and indirect effects of morphophysiological traits and grain yield components on dry grain yield of cowpea (Aquidauana, MS, Brazil, 2015).

\begin{tabular}{l|c|c|c|c|c|c|c}
\hline Effect & DF & DM & MSL & NBP & GPL & GPM & NGP \\
\hline Direct on YIE & 0.2975 & 0.2223 & 0.3069 & -0.3106 & -0.1288 & -0.2611 & 0.8651 \\
\hline Indirect via DF & - & 0.0448 & -0.0324 & 0.2249 & 0.0222 & 0.0415 & 0.0600 \\
\hline Indirect via DM & 0.0335 & - & -0.0476 & -0.0356 & 0.0132 & 0.0793 & 0.0296 \\
\hline Indirect via MSL & -0.0335 & -0.0658 & - & 0.0934 & 0.0058 & -0.0802 & -0.0955 \\
\hline Indirect via NBP & -0.0235 & 0.0497 & -0.0945 & - & 0.1094 & 0.1305 & -0.0012 \\
\hline Indirect via GPL & 0.0096 & -0.0076 & -0.0024 & 0.0454 & - & -0.0913 & 0.0878 \\
\hline Indirect via GPM & -0.0364 & -0.0931 & 0.0682 & 0.1097 & -0.1849 & - & -0.2693 \\
\hline Indirect via NGP & 0.1745 & 0.1152 & -0.2693 & 0.0033 & 0.5741 & 0.5848 & - \\
\hline Indirect via HGM & 0.0086 & 0.0182 & -0.0124 & -0.0054 & 0.0551 & 0.0419 & -0.1319 \\
\hline Total & 0.4111 & 0.2837 & -0.0835 & -0.0775 & 0.466 & 0.4453 & 0.6565 \\
\hline
\end{tabular}

DF: days to flowering; DM: days to physiological maturity; NBP: number of branches per plant; MSL: main stem length; GPL: green pod length; GPM: green pod mass; NGP: number of grains per green pod; HGM: hundred green grains mass; YIE: dry grain yield.

Among the primary production components, NGP obtained the greatest direct effect on the YIE with same signal and magnitude similar to that presented by the genotypic coefficient of correlation (Table 5). This indicates that this trait is the main determinant for the YIE behavior. The traits GPL and GPM had negative and direct effects of low magnitude (Table 6), and positive and medium magnitude correlations with the YIE (Table 5), which allows inferring, according to Vencovsky (1978), which indirect effects of these traits on YIE selection should be considered.

Primary components of grain yield (GPM, GPL, HGM and NGP) are related to each other, and this interaction affects the relationship of each with grain yield (Silva and Neves, 2011). Therefore, it is necessary to investigate these associations with path analysis. The analysis of the total coefficient of determination $\left(\mathrm{R}^{2}\right)$ indicates that the variables used partially explain (61.98\%) the behavior of the basic variable YIE and that other variables, not considered here, also influence the behavior of this trait.

\section{REFERENCES}

Andrade FN, Rocha MM, Gomes RLF, Freire Filho FR, et al. (2010). Estimativas de parâmetros genéticos em genótipos de feijão-caupi avaliados para feijão fresco. Rev. Ciên. Agron. 41: 253-258.

Genetics and Molecular Research 16 (2): gmr16029559 
Barroso LMA, Teodoro PE, Nascimento M, Torres FE, et al. (2016). Bayesian approach increases accuracy when selecting cowpea genotypes with high adaptability and phenotypic stability. Genet. Mol. Res. 15: 15017625. http://dx.doi. org/10.4238/gmr. 15017625

Bertini CHCM, Teófilo EM and Dias FTC (2009). Divergência genética entre acessos de feijão-caupi do banco de germoplasma da UFC. Rev. Ciên. Agron. 40: 99-105.

Câmara TMM, Bento DAV, Alves GF, Santos MF, et al. (2007). Parâmetros genéticos de caracteres relacionados à tolerância à deficiência hídrica em milho tropical. Bragantia 66: 595-603. http://dx.doi.org/10.1590/S0006$\underline{87052007000400009}$

Castoldi FL (1991). Análises das interpretações entre rendimentos e diversas características agronômicas do feijoeiro (Phaseolus vulgaris L.). Dissertação (Mestrado em Genética e Melhoramento). Universidade Federal de Viçosa, Viçosa.

Correa AM, Gonçalves M, Destro D and Souza LCF (2003). Estimates of genetics parameters in common bean genotypes. Crop Breed. Appl. Biotechnol. 3: 223-230. http://dx.doi.org/10.12702/1984-7033.v03n03a07.

Correa AM, Ceccon G, Correa CMA and Delben DS (2012). Estimativas de parâmetros genéticos e correlações entre caracteres fenológicosemorfoagronômicos em feijão-caupi. Rev. Ceres 59:88-94.http://dx.doi.org/10.1590/S0034-737X2012000100013

Correa AM, Braga DC, Ceccon G, Oliveira LVA, et al. (2015). Variabilidade genética e correlações entre caracteres de feijão-caupi. Rev. Agroamb. 9: 42-47.

Cruz CD (2013). GENES: a software package for analysis in experimental statistic and quantitative genetic. Acta Sci. Agron. 35: 271-276. http://dx.doi.org/10.4025/actasciagron.v35i3.21251

Cruz CD, Regazzi AJ and Carneiro PCS (2012). Modelos biométricos aplicados ao melhoramento genético. Editora UFV, Viçosa.

Falconer DS (1987). Introdução à genética quantitativa. Imprensa Universitária Federal de Viçosa, Viçosa.

Freire Filho FR, Ribeiro VQ, Barreto PD and Santos AA (2005). Melhoramento Genético. In: Feijão-caupi: avanços tecnológicos (Freire Filho FR, Lima JAA and Ribeiro VQ, eds.). EMBRAPA, Brasília.

Johnson HW, Robinson HF and Comstock RE (1955). Genotypic and phenotypic correlations in soybeans and their implications in selection. Agron. J. 47: 477-483. http://dx.doi.org/10.2134/agronj1955.00021962004700100008x

Regis JAVB, Molinas VS, Santos A, Correa AM, et al. (2014). Estimativas de parâmetros genéticos em genótipos de feijão-caupi de porte ereto e semiereto. Rev. Agrarian 7: 11-19.

Santos A, Ceccon G, Davide LMC, Correa AM, et al. (2014a). Correlations and path analysis of yield components in cowpea. Crop Breed. Appl. Biotechnol. 14: 82-87. http://dx.doi.org/10.1590/1984-70332014v14n2a15

Santos A, Ceccon G, Rodrigues EV, Teodoro PE, et al. (2015). Adaptability and stability of cowpea genotypes to Brazilian Midwest. Afr. J. Agric. Res. 10: 3901-3908 http://dx.doi.org/10.5897/AJAR2015.10165.

Santos JAS, Teodoro PE, Correa AM, Soares CMG, et al. (2014b). Desempenho agronômico e divergência genética entre genótipos de feijão-caupi cultivados no ecótono Cerrado/Pantanal. Bragantia 73: 377-382. http://dx.doi. org $/ 10.1590 / 1678-4499.0250$

Santos JAS, Soares CMG, Corrêa AM, Teodoro PE, et al. (2014c). Agronomic performance and genetic dissimilarity among cowpea [Vigna unguiculata (L.) Walp.] genotypes. Glob. Adv. Res. J. Agr. Sci. 3: 271-277.

Silva JAL and Neves JA (2011). Componentes de produção e suas correlações em genótipos de feijão-caupi em cultivo de sequeiro e irrigado. Rev. Ciên. Agron. 42: 702-713.

Teodoro PE, Barroso LMA, Nascimento M, Torres FE, et al. (2015a). Redes neurais artificiais para identificar genótipos de feijão-caupi semiprostrado com alta adaptabilidade e estabilidade fenotípicas. Pesqui. Agropecu. Bras. 50: 10541060. http://dx.doi.org/10.1590/S0100-204X2015001100008

Teodoro PE, Nascimento M, Torres FE, Barroso LMA, et al. (2015b). Perspectiva Baysiana na seleção de genótipos de feijão-caupi em ensaios de valor de cultivo e uso. Pesqui. Agropecu. Bras. 50: 878-885. http://dx.doi.org/10.1590/ $\underline{\text { S0100-204X2015001000003 }}$

Teófilo EM, Dutra AS, Pitombeira JB, Dias FTC, et al. (2008). Potencial fisiológico de sementes de feijão caupi produzidas em duas regiões do Estado do Ceará. Rev. Cien. Agron. 39: 443-448.

Torres FE, Sagrilo E, Teodoro PE, Ribeiro LP, et al. (2015a). Número de repetições para avaliação de caracteres em genótipos de feijão-caupi. Bragantia 74: 161-168. http://dx.doi.org/10.1590/1678-4499.0393

Torres FE, Teodoro PE, Sagrilo E, Correa AM, et al. (2015b). Interação genótipo x ambiente em genótipos de feijão-caupi semiprostrado via modelos mistos. Bragantia 74: 255-260. http://dx.doi.org/10.1590/1678-4499.0099

Torres FE, Teodoro PE, Rodrigues EV, Santos A, et al. (2016). Simultaneous selection for cowpea (Vigna unguiculata L.) genotypes with adaptability and yield stability using mixed models. Genet. Mol. Res. 15: 15028272. http://dx.doi. org/10.4238/gmr. 15028272

Vencovsky R (1978). Herança quantitativa. In: Melhoramento e produção do milho no Brasil (Paterniani E, ed.). ESALQ, Piracicaba.

Wright S (1923). Theory of path coefficients. Genetics 8: 239-255.

Genetics and Molecular Research 16 (2): gmr16029559 